PART I

Conceptualizing The Spectacle 

CHAPTER 3

\title{
The Integrated Spectacle: Towards Aesthetic Capitalism
}

\author{
Vanni Codeluppi
}

\section{Introduction}

The 1970s changed the social condition described in the previous decade by Guy Debord in The Society of the Spectacle (1977). But it can be said that the 'integrated spectacle', mentioned by Debord in the Comments on the Society of the Spectacle (2011), has come true: a model dominated by representations in which the spectacle is totally merged with the social culture, and the individual experience of reality is increasingly filtered by media. A model therefore that we can also call 'aesthetic capitalism'. The main objective of this chapter is to demonstrate that Guy Debord's 'integrated spectacle' and 'aesthetic capitalism' are the results of the intense process of mediatization and aestheticization that started in the 1970s in Western societies. This is a process that originates from the progressive extension of the model of factory production to the whole range of cultural and social experiences of the individuals.

Thus, in order to understand what is happening today, it is probably useful to go back in time and analyse the particular historical phase from which the changes

How to cite this book chapter:

Codeluppi, V. 2017. The Integrated Spectacle: Towards Aesthetic Capitalism.

In: Briziarelli, M. and Armano, E. (eds.). The Spectacle 2.0: Reading Debord in the

Context of Digital Capitalism. Pp. 51-66. London: University of Westminster Press.

DOI: https://doi.org/10.16997/book11.c. License: CC-BY-NC-ND 4.0 
currently taking place originated. In this respect, the 1970s were a particularly crucial phase. Our argument in support of this thesis will be based primarily on our analysis of a number of relevant films. In some cases, in fact, films have been able to track the processes of change taking place in the social sphere with a great deal of accuracy. Thus, in the pages that follow we will be examining some films that have a deep connection with the changes which occurred in the 1970s.

We will also, however, analyse that particular decade from a broader perspective in order to highlight its specific nature more clearly. We will thus consider the changes that characterized the 1970s from the point of view of production models as well as of technology and media culture, probably the main force operating in the economic and social processes of contemporary capitalism (Kellner 1995, 2003).

\section{Alien and Blade Runner: A New Social Model Emerges}

The first film, Alien, was directed by the film maker Ridley Scott in 1979 and was in some respects epochal. At the time, what probably struck the audiences most was the lack of prospects for the human protagonists of the story recounted by the film: they were in fact prisoners inside a huge spaceship - that is a microsociety and an effective metaphor of our social life - carrying a fierce, raging monster. The monster-alien seemed to come from the outside but was largely unclassifiable as it had no identity or boundaries and took the shape of the bodies it entered. For this very reason, unlike previous science-fiction films, viewers were made to wonder whether in fact the monster might have come from within the spaceship, in other words, not be entirely an Other or foreign being. Ultimately the film exploited that feeling of shock which comes about when the Other suddenly reveals itself to be an Identical being.

A few years after directing Alien, Ridley Scott directed Blade Runner (1982). The film occasioned countless discussions primarily due to the extreme care with which it was made at the formal level but also because its atmosphere was consistent with a typically postmodern aesthetic taste where architectural features, furnishings, objects and signs intertwined different periods and expressive styles with great freedom. It should also be noted that Blade Runner did not give a realistic representation of the city of Los Angeles, which is a sprawling expanse of bungalows and small, ranch-style homes (Davis 1992, 2006); but if we consider that in our imagination Los Angeles represents the city of fiction par excellence (thanks to Hollywood and Disneyland in particular), it seems clear that a more suitable urban setting for the film could not have been found. This explains why Blade Runner was so successful in creating the quintessential model of the postmodern metropolis. It portrayed a metropolis spread out across the territory and without a history, just like Los Angeles.

The strong interest aroused by Blade Runner, however, derives principally from the fact that, as David Harvey has pointed out, the events recounted by 
the film are centred around replicants, namely human beings who only live for four years but lead a particularly intense life:

The replicants exist, in short, in that schizophrenic rush of time that Jameson, Deleuze and Guattari, and others see as so central to postmodern living. They also move across a breadth of space with a fluidity that gains them an immense fund of experience. Their persona matches in many respects the time and space of instantaneous global communications (Harvey 1990, 309).

Replicants, in other words, can be seen to correspond to that compression of time and space which characterizes today's advanced stage in the evolution of capitalism, where technology has increasingly encroached on individual subjectivity. And within that stage capital has become global and therefore indifferent to the specific needs of communities and local areas. It is no accident that in the film the construction processes used for building the replicants are typically post-Fordist, that is, based on the externalization and the division of working processes allocated to different specialists and different locations. The sophisticated technological eyes of the replicants, for example, are made in a basement belonging to an immigrant of eastern origins in not altogether hygienic conditions - a place therefore quite similar to where today's technologically advanced goods are frequently produced for the world's leading brands (Klein 2010).

What makes Blade Runner particularly congruent with the current evolutionary stage of capitalism, however, is above all the dark and grim representation of urban life conveyed by the film. The metropolis of the future is in fact depicted as an extremely dangerous place, a disturbing nightmare where all one can hope for is to manage to survive. What is missing in Blade Runner is thus the idea of trust in a positive social model. Individuals are trapped inside the society in which they find themselves - a society undergoing a deep crisis and that has lost the temporal dynamic capable of connecting the present with the past and the future.

And here too, just as in Alien, danger lies hidden inside the Other, concealed, that is, in the foreign or different being. But the Other is now exactly the same as us, a replicant that looks just like us, in every possible way. We can therefore no longer trust our own kind, on the contrary, these subjects are all the more dangerous because they are indistinguishable from us. All this comes through even more vividly in the re-edited version of the film directed by Scott in 1992, the so-called 'Director's cut', in which Rick Deckard, the lead character of the film played by Harrison Ford, is tasked with hunting down the replicants but is in turn the object of explicit suggestions that he is a replicant himself. It is therefore no longer possible to define with any accuracy who the Other actually is - the enemy to be fought - and this makes it impossible to have some form of control over him. The resulting human living condition is one in which danger can be found lurking anywhere and takes the form of a generalized threat that is difficult to confront. 
Blade Runner, alongside Alien, is a lucid account of the falling apart of the common social fabric developed from the Fifties onwards that were a distinguishing feature of Western societies during the era of intense industrialization. As Gianni Canova has argued:

Once the brief season of Neo-capitalist optimism was over, and with the crumbling of the illusion that it was possible to absorb every form of otherness thanks to the healthy effects of a technological rationality capable of satisfying needs and levelling or concealing differences, the Western imagination rediscovered - as early as the second half of the 1960s - an abrupt and violent 'return of the removed': the Other re-emerged with a shock effect from underneath the shell of a ratio weakened and shaken up by the conflicts of the previous decade, and gathered onto itself the persecuting fears of foreignness (2000, 97, our translation).

Alien and Blade Runner thus provided a clear illustration of the fact that human reason had started to become impotent vis-à-vis the Other. Essentially, what these two films highlighted most of all was the crisis of the Western human being as a subject capable of interpreting and moulding the world according to his will. Previously, in fact, the act of seeing by the human being was viewed as an act of knowledge-acquisition and therefore of dominance over reality, but now we can no longer trust what the eye sees. It is no coincidence that the beginning of Blade Runner we are faced with the memorable full-screen shot of a wide-open blue eye reflecting images of flaring fires rising up from an infernal, night-time Los Angeles. It is a sort of 'eye-mirror', that is, an eye that does no more than reflect external reality and no longer belongs to a subject endowed with the ability to act upon it. Hence it is not disturbing to those looking at it. Viewers of the film do not perceive the eye as belonging to someone who is seeing them but as a mirror, simply reflecting an urban space that they are not acquainted with and are thus not engaged by. Then again, it seems to be the eye of one of the many replicants that humans use as tools to explore areas of the Off-world considered as being too hazardous for themselves to venture into. In this sense, it is an 'eye-prosthesis' that enables humanity to see even places where it cannot be physically present. If modernity sprang from the Renaissance with the invention of perspective, enabling individuals to establish a viewing point from which they could dominate the world, in today's postmodern world by contrast the prevailing trend is a lack of distinction between the eye and the reality it is looking at, that is, between the subject and the object of vision. The eye of the replicant shown at the beginning of Blade Runner thus constitutes an explicit metaphor of the serious crisis that human subjectivity is going through.

Since the eyes of the replicants are artificial, their dehumanized vision also prefigures the social predominance later acquired by the digital image - that is, an overall image that can be totally independent of the act of vision performed by the human eye. It is a machine-generated image that, as frequently 
happens in Blade Runner, can easily be manipulated and falsified. And yet it seems increasingly clear that 'while today the powers of the eye are growing, in actual fact the amount of knowledge acquired is proportionally decreasing. The space of the image can say nothing, or almost nothing, about the world: it is an autonomous entity, with its own laws, its non-Euclidean geometries' (Bertetti and Scolari 2002, 42, our translation). Previously, photography used to be a document, a proof testifying to the presence of the photographed subject, whereas what is happening now more and more is that the subject tends to exit from the scene and, with it, its own photographic image disappears as well. Nevertheless, the digital image is today operating like a sort of 'fuel' for 'aesthetic capitalism. The fluidity and the liquidity of the digital bits are the ideal instruments of the processes that create economic value.

Film such as Alien and Blade Runner, but partly also like John Carpenter's The Thing (1982), David Cronenberg's Videodrome (1983) and James Cameron's The Terminator (1984), can be seen as the result of that period of radical change that characterized the 1970s in the West and which led to a new evolutionary stage of capitalism: 'biocapitalism' (Codeluppi 2008). It is certainly the case that Western societies underwent several periods of intense change in the twentieth century. One has only to think of the Twenties and Thirties for example. But the most radical changes that would eventually alter the economic and social structure of the Western world so profoundly arguably occurred during the 1970s. It is significant in this respect that the architecture critic Charles Jencks (1977) has dated the shift from modernity to post-modernity to the early 1970s, 1972 to be precise, making it coincide with the decision to demolish the Pruitt-Igoe housing project in Saint Louis, Missouri - a very effective version of the 'machine for living in' conceived by Le Corbusier, the most representative architect of Modernism. The 1970s therefore deserve to be closely examined because many of the roots of the social changes that subsequently developed can be traced to this historical phase.

\section{The 1970s: From Conflicts to the Network}

In the world's most advanced economies during the mid-twentieth century, socalled 'white-collar workers', that is, those employed in management, technical and clerical positions, started to have equal weight as 'blue-collar workers', that is, manual labour. Thus, by 1969 Alain Touraine could already talk about 'postindustrial society' (1971). It was the subsequent decade, however, that proved decisive for the shift to the post-Fordist model of production. This model radically challenged the traditional Fordist system developed in the United States in the early twentieth century based on large factory assembly lines and on an unqualified, poorly educated workforce yet capable of producing, by means of very simple operations, standard goods available to huge masses of consumers at affordable prices. 
With the onset of post-Fordism, the large industrial factory was gradually dismembered and took the form of a network structure geographically scattered across territories and made up of small centres of production as well as a workforce fragmented into many small, increasingly mobile and precarious units. This consequently changed the conception of the factory which, despite the geographical scattering of production, became 'integrated' along the lines of the model developed in the 1960s by the Japanese company Toyota which sought to combine capital and labour into a single production effort. Accordingly, the identity of individuals no longer derived from the fact that they belonged to a particular social class but from their awareness that they were participating in a joint production plan.

The underlying causes of all this are manifold. Firstly, we should bear in mind that the youth and workers' struggles of the late 1960s had eroded companies' profit margins and aroused major concerns among entrepreneurs who felt the need to experiment with new production strategies that would enable them to exercise greater control over the workforce. Hence, as Daniel Cohen (2006) has argued, the birth of the decentralized, network enterprise can be interpreted as an instance of the class struggle, in view of the fact that the first companies to be restructured in the United States were those with the most strongly unionized labour forces. Indeed, a major reorganization of the capitalistic system clearly took place during that historical phase that led, once again in the United States, to the loss of 3,400,000 jobs between 1977 and 1986 following the relocation of capital and production processes to areas of the planet such as Asia and Mexico, where greater exploitation of the workforce was possible (Cartosio 1998).

It should also be noted that one of the factors which drove businessmen to seek greater flexibility of production was the intrinsic evolutionary logic of the industrial system - a flexibility, moreover, made possible by the reduction in transport costs and the new availability of the peculiar network structure that distinguishes the way in which computer technologies work. In 1976 the innovative Apple II personal computer model was commercialized and thanks to the introduction of PCs in every office and related digitization, work basically became transformed into an activity of reception, processing and transmission of information. As a result, work itself could be made to resemble information, in other words, it could be made flexible and nomadic.

Developing in parallel with this was the shift towards what various authors have termed 'cognitive capitalism' (Azaïs et al. 2000, Moulier Boutang 2012), founded on the central role played by the economy of knowledge. This kind of capitalism is far more efficient than that which hinges exclusively on freedom of the market. This is because knowledge is by its very nature a widely available resource and renders obsolete the 'law of rarity' that used to prevail in the age of classical industrial production, according to which the material resources necessary for industrial production were scarce. Most importantly, this new type of capitalism is able to make use of the invaluable tool of the Internet, which gives companies the opportunity to exploit the fruits of cooperation 
between different actors and thus to access extremely effectively the resources they need.

Added to all this was also the drive for change caused by the drastic slowdown of the rate of economic development in the world's major advanced countries from 1975, and especially by the heavy economic crisis that set in during the first half of the 1970s. This crisis was particularly shocking to society because it came after a long period of economic development and prosperity. It now became clear that to produce goods which would then almost automatically find the corresponding demand for them was no longer sufficient. Instead, it was necessary to produce not only goods but also consumers; in other words, individuals had to be educated by nurturing their awareness of the pleasure they would be able to gain from consuming. Accordingly, society required all consumers to take personal responsibility in terms of their duty to consume and thus participate in the production-consumption process (Bauman 2002).

A phenomenon probably connected with all this is the development of the personality cult that started to grow throughout the Western world precisely from the late 1960s and which Christopher Lasch has called the 'culture of narcissism' (1981). The feminist movement's challenge to patriarchal society and the different forms of expression of women's emancipation (including female employment, birth control methods, sexual freedom, divorce and so on) led to the disintegration of the traditional family model and to a growth in the level of individualism (Castells 2009b). At the same time, however, the disappointment caused by the failure of the political movements of the 1960s and 1970s to fulfil promises of social change and personal realization gradually turned the original plans for the transformation of society into more modest goals associated with the transformation of every individual's personal image (Codeluppi 2002). This led to a heightened interest in achieving personal health and physical fitness with an explosion of sporting practices such as jogging. From the Eighties onwards, many women also started to practise a variety of physical activities for the first time, leading for instance to the widespread success of aerobics. Consequently, clothes and the human body more generally, gradually became more important in the culture of Western societies during those years a fact demonstrated for example by the popularity gained in that period by dancing, discos and so-called 'disco music'. It is no coincidence that, following the worldwide success achieved in 1977 by the film Saturday Night Fever starring the actor John Travolta, such phenomena have often been grouped under the label of 'Travoltism'.

But the impetus to focus on personal goals found forms of personal realization in the economic domain as well, in terms of both production and consumption. On this subject, the futurologist Alvin Toffler, in his book The Third Wave (1980), charted these social changes at the time and theorized on a figure he called 'prosumer' which combines the producer and the consumer into a single entity. During subsequent decades this figure became key for the development of the consumer world. The race towards the personalization of 
consumer choices has in fact been a powerful driver of economic development right through to the present time. The growing personalization of consumer choices is not then so much the result of the consumer's independence but above all of a need imposed by the economic system.

Through the figure of the prosumer, the economic system is thus capable of securing flexibility not only of production but also of consumption (Ritzer and Jurgenson 2010, Flichy 2010). It is therefore easier for it to employ everything that consumers generate within society, in other words, to use the work performed inside what might be regarded as a genuine 'social factory'. It is in fact becoming increasingly clear that whereas the operating mechanisms of traditional factories relied on the exploitation of their internal workforce, today's firms accumulate value mostly from the outside, resorting daily to consumers and society at large, using that surplus of innovations, ideas and creativity that individuals produce through their everyday behaviours and experiences (Bifo Berardi 2009, Scholz 2012).

\section{From Information to Sensation}

In 1967, Guy Debord, who had founded Situationist International in Italy ten years earlier, published The Society of the Spectacle (1977) in France. The book launched a radical critique against affluent Western societies and because of this it became a kind of manifesto for the youth uprisings of May 1968. Some years later, in 1988 to be precise, Debord argued in his book Comments on the Society of the Spectacle (2011) that alongside the two traditional forms of spectacular society - namely the 'concentrated spectacle' (typical of totalitarian regimes) and the 'diffuse spectacle' (typical of Western consumer societies) - there had gradually developed the 'integrated spectacle' model. The latter combines the two previous forms with the result that spectacle becomes so predominant in society that nothing else can exist outside of it.

The economic system's ability to 'put to work' today the whole of society relies chiefly on the growing process of spectacularization of daily life and consumption that has become a distinctive feature of today's hypermodern stage of social evolution. In order to take advantage of this situation, companies have to use their brands as a means of communication, that is, as relational tools and independent domains in which producers and consumers can build connections between each other. At the economic level, brands are in fact the more effective the more they are able to develop an identity that is able to act as a centre of social relations. This explains why company brands are becoming so important in the type of culture characterizing today's hypermodern societies.

It is therefore worth taking a closer look at the way in which such brands actually work. Antonella Giardina (2011) has shown that what they essentially seek to do is attribute economic value to the various kinds of expressive forms belonging to their symbolic world. Thus colours, sounds or particular 
aesthetic forms are tracked in order to be monetized; at the same time, they also become fundamental tools in the strategy of differentiation that every brand constantly strives to pursue on the market vis-à-vis its competitors. Given the key role played by brands at the social level, this is a clear demonstration of the fact that advanced capitalist societies are increasingly entering a stage that seems to be dominated by aesthetics. It is a stage primarily centred on the ability to stimulate particularly intensely the sphere of human sensibility, namely all those sensations that individuals perceive through their bodies. Moreover, in order to develop, this stage has required aesthetic production to become fully integrated within the process of goods production in general, and hence that the goods-related economic system should undergo the same process of abstraction and flexibilization, that is, become part of that regime of variable and constantly moving communication flows which has always been a distinctive feature of the world of aesthetics and social culture.

In order for all this to occur, aesthetics itself has obviously had to be changed as well. According to Andrew Darley (2000), in fact, what we are mainly seeing today is an 'aesthetic without depth' whose chief characteristic is the predominance of style, appearance, form, ornament and sensation rather than meaning and interpretation. This kind of aesthetic had already started to develop during the second half of the nineteenth century thanks to the numerous tools of communication that appeared on the scene at the time (the diorama, the magic lantern, Luna Parks, photography, cinema and so on), but the subsequent advances made by communication technologies contributed significantly to its intensification. Moreover, in view of the high rate of usage by individuals of communication tools characterized by a virtual and constantly moving visual language (cinema as well as television and mobility media), Anne Friedberg's (1993) statement made some twenty ago that we are facing a genuinely 'mobilized and virtual gaze' has become increasingly true. Today we can therefore claim that 'The spectator of visual culture is positioned first and foremost as a seeker after unbridled visual delight and corporeal excitation' (Darley 2000 169).

Walter Benjamin (1999) was the first to address the subject of the social diffusion of aesthetics in his essay The Work of Art in the Age of Mechanical Reproduction, published for the first time in 1936. When he used the term aestheticization, however, he explicitly intended to refer to the specific realm of politics. Three years later, in the text On Some Motifs in Baudelaire, the renowned German intellectual showed a deeper awareness of the key role played by the process of aestheticization within the social system. He argued, for instance, that 'The replacement of the older narration by information, of information by sensation, reflects the increasing atrophy of experience' $(1999,155)$.

Benjamin thus captured vividly the idea of how in capitalist societies sensation gradually takes the place of information. Later in that same essay he posited a precise connection between the sensations experienced by passersby in the moving crowd of the metropolis and the process of standardized 
production in the factory; in a similar way he drew a connection between the latter and the mobilization of vision that characterizes the experience of viewing the cinematographic spectacle:

In a film, perception in the form of shocks was established as a formal principle. That which determines the rhythm of production on a conveyor belt is the basis of the rhythm of reception in the film' $(1999,171)$.

Capitalism, according to Benjamin, therefore extends the model of factory production to the whole gamut of sensible experiences and does so by applying it not only as an economic model but, in a more subtle way, as a cultural model capable of generating experiences.

As a matter of fact, the subject of the social consequences of the aestheticization process had already been previously addressed by Georg Simmel (Frisby and Featherstone 1997), who believed that the true nature of modern societies could only be grasped if one had a thorough understanding of the social sphere of aesthetics. In other words, the social system could be effectively interpreted by analysing the way in which artistic languages are applied on a daily basis to many different forms of expression (such as fashion, design, advertising and so on). If this was true during the age of Simmel then it is even more valid today, when the immaterial components of the economy and society have undergone more than a century of development. It now also seems clear, however, that in recent years aestheticization has been a prerequisite for the commodification process to be able to develop socially, where the diffusion of aesthetics in everyday life has facilitated the entry of every object, as well as every individual, institution and event, into the circuit of the market and of the consumer world (Assouly 2008, Lipovetsky and Serroy 2013).

\section{Aesthetics and the Metropolis: The Case of Birmingham}

Drawing on the insights of Benjamin and Simmel, Giacomo Ravesi (2011) has illustrated the links in today's advanced societies between the metropolitan experience and media languages. These have developed not only because urban spaces are being increasingly invaded by ubiquitous video screens and media messages but also because a relationship of mutual interpenetration has grown between the city and media. This phenomenon has reached such a scale that it can be argued that 'the image of the contemporary metropolis has now definitively spilled into the "flow" of media communication' (Ravesi 2011, 30, our translation).

But what is interesting about this is the fact that this process of fusion of metropolises within the media flow now circulating in society seems to be driven by that media flow itself. To that extent therefore, this media flow does not simply constitute an aesthetic form to be contemplated, but actually defines 
certain organizational criteria governing the ways through which individuals can have their own experience of the world. Yet it does so on the basis of that consumer culture which constantly runs through it and without which it would not be able to function.

This is clearly demonstrated by the case of the city of Birmingham in England. As is widely known, violent inter-racial clashes broke out in certain neighbourhoods of London and other cities across England over several days during August 2011; but the city that was really 'on fire' was Birmingham, Britain's second most populous city with just over a million inhabitants. At the symbolic level, this constituted an odd historical nemesis. The Centre for Contemporary Cultural Studies at the University of Birmingham was in fact where Britain's most important school of cultural studies since World War II was born and developed (Procter 2004). The school made the spectacular expressive styles of youth subcultures (from the Mods to the Punks) the core of its studies and put forward the most effective theoretical explanation of the underlying reasons for the birth of such subcultures and the way they operated. The golden age of the Birmingham School however lasted from the 1960s through to the 1980s, and it is perhaps no coincidence that the beginnings of its crisis coincided with the petering out of that social energy which, from the Fifties onwards, had led many youths in Britain to develop particularly clamorous and innovative subcultures.

According to the Birmingham School, subcultures represented the response that British youths were attempting to give to the opposing thrusts to which they were being subjected in the peculiar social situation in which they found themselves. Subcultures, in other words, were an attempt to resolve the contradiction felt by young people between on the one hand the kind of Puritanism traditionally embraced by the working class which their parents came from, and on the other the new hedonism put forward by the world of media. In particular, they found that the consumer culture they were beginning to be surrounded by was sparked by the developing economic boom of that time. From this standpoint, the Mods were exemplary. The slang and rituals adopted by members of this subculture made reference to their parents' traditional culture, while the clothes they wore and their musical tastes reflected the image set by affluent young consumers. Subcultures were thus the product of a search for synthesis between the forms of social adaptation developed by parents and those of their children. The subculture was a means of channelling the malaise of Britain's youths in a space that was non-threatening to society and weaker than the potentially destructive energy it might have been charged with. In other words, this malaise was transformed into an opposition that was symbolic in nature but, according to the interpretation put forward by the Birmingham school, nevertheless retained a will to social resistance with the potential to turn it into a political movement of open protest (Codeluppi 2002).

Today, the British subcultures which were the object of the Birmingham School's investigations have become distinctly weaker. In some cases they have 
become aware of those practices of absorption within media and commercial circuits that society habitually develops towards them and, in order to escape from these, they have shifted to physical and digital spaces in which they are difficult to see, but by so doing they have become less visible and consequently less powerful as well. More often, however, they have turned 'pop', that is, pure media and consumer phenomena, hardly distinguishable from the flows of messages and products coming directly out of the culture industry. Thus, if the interpretation of the Birmingham scholars is correct, a further element that has been lost is the peculiar ability of subcultures to act essentially as social cushions or 'shock-absorbers' and, as such, to reduce the impact of conflicts between youths and society. And this is one of the fundamental underlying reasons for the clashes that erupted in Birmingham and the rest of England in 2011.

What happened in Birmingham in the summer of 2011 can be explained not only by the weakening of the mechanisms of 'conflict-absorption', but also by the considerable changes that have occurred in the social and economic fabric of this city. Among these we should note the particularly powerful impact of delocalization of industrial production to other areas of the planet and the closing down of major factories such as that of the car manufacturer MG Rover.

A key element to be considered, however, is that since the twelfth century Birmingham had been home to the Bull Ring, the oldest market in England. Today, the area once occupied by the Bull Ring is mostly covered in shops. Symbolically, the location of the once thriving market has been taken up by a large department store that has even adopted its name: the Selfridges Bullring. It consists of a gigantic sausage-shaped construction covered by 15,000 round aluminium mirrors. This striking building, designed by the architectural stars from the firm Future Systems, was constructed in a town centre that had been the object of a vast 'urban clean-up' involving the renovation of historical streets, the creation of new squares and, most importantly, the replacement of traditional shops with global brand stores. There is actually no difference from what has happened to the majority of cities both in Britain and other European countries, where old town centres have been deprived of their very roots and identity - an identity that had been painstakingly built over the centuries, made up of venues, buildings, conduct and rituals which had gradually come to be part of a common cultural heritage.

This has created a vacuum that has progressively been filled by what Boeri (2011) has termed the 'anti-city', namely a flow of energy spreading more and more widely and which by degrees is fragmenting traditional urban society, eliminating differences between centres and suburbs and doing away with the boundaries between the city and the countryside. It is also, however, a flow that is gradually blending with consumer culture, a culture which currently takes virtually identical forms in all Western cities. Yet it is also a fact that individuals have increasingly built their identity upon that particular culture instead of choosing as their point of reference a specific cultural heritage solidly established over time. We only feel we are citizens, it would seem, if we consume. 
But while people find that due to the economic crisis they now have little money to spend on their shopping, they nevertheless still feel they have a right to own those goods - goods that they are tempted by daily by shop windows and, most of all, video screens teeming with advertising messages. And, if necessary, they will enforce their right to own such goods even by illegal and violent means - which is in fact precisely what happened in Birmingham and across England in 2011. Otherwise they do not feel like full citizens.

Birmingham has a population of just over one million and, as such, can be compared to many medium-sized cities across Europe. In recent years these cities have frequently undergone the same process of 'emptying out' of their town centres and suffered the same crisis of their traditional identities which, in this case too, are being replaced by a process of aestheticization whose main emphasis tends to be on consumer culture.

\section{Conclusions}

From the films we have analysed, we have seen how, during the 1970s, the Western individual and his capacity to interpret and change reality started going through a serious crisis - a crisis reflected particularly by this individual's inability to trust what his eye can see.

These films have also shown that the processes of change currently taking place in Western societies started in the 1970s, triggered by the development of typically post-Fordist production processes. These involved the externalization and the division of corporate manufacturing stages into different specialist areas and different locations. These production stages centred on manufacturing flexibility and were made possible by the reduction in transport costs coupled with that newly-available and peculiar network structure that characterizes the way information technology works.

Through our analysis of the selected films we have also seen how the 1970s ushered in a process in which immaterial components started to become increasingly pervasive in the economy and throughout society, a trend that has led to widespread aestheticization, that is, the application of the aesthetic dimension, which was once seen exclusively in the world of art, to the goods circulating throughout society and in the sphere of people's everyday lives.

Finally, we have seen how these phenomena are particularly strong in today's urban and metropolitan areas, where a process of fusion is taking place with the media flow spreading across the social culture. This flow does not simply constitute an aesthetic form to be contemplated but it also actually defines certain criteria that govern the way in which individuals can experience the world. And, to that end, it relies on the consumer culture that constantly permeates it, and without which it would not be able to function.

Thus, if today we are able to talk about Guy Debord's 'integrated spectacle' and about 'aesthetic capitalism', it is due to the process of mediatization and 
aestheticization that started in the 1970s and which is so pervasive in the daily lives of present-day capitalist societies; a process that enables firms to create economic value by relying first and foremost on the work performed daily by individuals, namely the countless innovations, ideas and creative contributions they produce every day through their behaviours and experiences.

\section{References}

Amin, Ash, ed. 1994. Post-Fordism: A Reader. Oxford: Blackwell.

Assouly, Olivier. 2008. Le capitalisme esthétique. Essai sur l'industrialisation du gout. Paris: Les Éditions du Cerf.

Azaïs, Christian et al., eds. 2000. Vers un capitalisme cognitif. Paris: L'Harmattan. Bauman, Zigmunt. 2002. Liquid Modernity. Cambridge, UK: Polity Press.

Benjamin, Walter. 1999. Illuminations. London: Pimlico.

Bertetti, Paolo and Carlos Scolari, eds. 2002. Lo sguardo degli angeli: Intorno e oltre Blade Runner. Torino: Testo \& Immagine.

Bifo Berardi, Franco. 2009. The Soul at Work: From Alienation to Autonomy. Los Angeles, CA: Semiotext(e).

Boeri, Stefano. 2011. Lanticittà. Roma-Bari: Laterza.

Boltanski, Luc and Eve Chiapello. 2007. The New Spirit of Capitalism. London: Verso.

Boyer, Marie Cristine. 1996. Cybercities. New York: Princeton Architectural Press.

Bukatman, Scott. 1997. Blade Runner. London: British Film Institute.

Canova, Gianni. 2000. Lalieno e il pipistrello: La crisi della forma nel cinema contemporaneo. Milano: Bompiani.

Cartosio, Bruno. 1998. L'autunno degli Stati Uniti. Milano: Shake.

Castells, Manuel. 2009a. The Rise of the Network Society: The Information Age: Economy, Society and Culture, Vol. 1. Oxford: Wiley Blackwell.

Castells, Manuel. 2009b. The Power of Identity: The Information Age: Economy, Society and Culture, Vol. 2. Oxford: Wiley Blackwell.

Codeluppi, Vanni. 2002. Che cosè la moda. Roma: Carocci.

Codeluppi, Vanni. 2008. Il biocapitalismo: Verso lo sfruttamento integrale di corpi, cervelli ed emozioni. Torino: Bollati Boringhieri.

Codeluppi, Vanni. 2012. The Return of the Medium. Communication Theories from Early Newspapers to the Internet. Saarbrücken, DE: Lap Lambert Academic Publishing

Cohen, Daniel. 2006. Trois leçons sur la société post-industrielle. Paris: Seuil.

Darley, Andrew. 2000. Visual Digital Culture: Surface Play and Spectacle in New Media Genres. London: Routledge.

Davis, Mike. 1992. Beyond Blade Runner: Urban Control: The Ecology of Fear. New York: The New Press.

Davis, Mike. 2006. City of Quartz: Excavating the Future in Los Angeles. London: Verso. 
Debord, Guy. 1977 [1967]. The Society of the Spectacle. London: Practical Paradise Production.

Debord, Guy. 2011. Comments on the Society of the Spectacle. London: Verso.

Flichy, Patrice. 2010. Le sacre de l'amateur: Sociologie des passions ordinaires à l’ère numérique. Paris: Seuil.

Foster, Hal. 1985. Postmodern Culture. London: Pluto Press.

Friedberg, Anne. 1993. Window Shopping: Cinema and the Postmodern. Berkeley: University of California Press.

Friedberg, Anne. 2009. The Virtual Window: From Alberti to Microsoft. Cambridge MA: The MIT Press.

Frisby, David and Mike Featherstone, eds. 1997. Simmel on Culture: Selected Writings. London: Sage.

Giardina, Antonella. 2011. Il marchio demiurgo: Identità strategica nell'orizzonte estetico. Milano: Lupetti-Editori di Comunicazione.

Goldman, Robert and Stephen Papson. 2011. Landscapes of Capital: Representing Time, Space, and Globalization in Corporate Advertising. Cambridge, UK: Polity Press.

Gottdiener, Mark. 1997. The Theming of America: Dreams, Visions, and Commercial Spaces. Boulder, CO: Westview Press.

Hannigan, John. 1998. Fantasy City: Pleasure and Profit in the Postmodern Metropolis. London: Routledge.

Harvey, David. 1990. The Condition of Postmodernity: An Enquiry into the Origins of Cultural Change. Oxford: Blackwell.

Jencks, Charles. 1977. The Language of Post-Modern Architecture. London: Academy.

Kellner Douglas. 1995. Media Culture: Cultural Studies, Identity and Politics Between the Modern and the Postmodern. London-New York: Routledge.

Kellner Douglas. 2003. Media Spectacle. London-New York: Routledge.

Klein, Naomi. 2010. No Logo. New York: Picador.

Lasch, Christopher. 1991. The Culture of Narcissism: American Life in an Age of Diminishing Expectations. New York: W. W. Norton \& Co.

Lash, Scott and Celia Lury. 2007. Global Culture Industry: The Mediation of Things. Cambridge, UK: Polity Press.

Lipovetsky, Gilles and Serroy, Jean. 2013. L'esthétisation du monde: Vivre à lâge du capitalisme artiste. Paris: Gallimard.

Marazzi, Christian. 2008. Capital and Affects: The Politics of the Language Economy. Los Angeles, CA: Semiotext(e).

Menarini, Roy. 2001. Ridley Scott: Blade Runner. Torino: Lindau.

Miles, Steven. 2010. Spaces for Consumption: Pleasure and Placelessness in the Post-Industrial City. London: Sage.

Moulier Boutang, Yann. 2012. Cognitive Capitalism. Cambridge, UK: Polity Press. Procter, James. 2004. Stuart Hall. London: Routledge.

Ravesi, Giacomo. 2011. La città delle immagini: Cinema, video, architettura e arti visive. Soveria Mannelli: Rubbettino. 
Ritzer, George and Nathan Jurgenson. 2010. 'Production, Consumption, Prosumption: The Nature of Capitalism in the Age of the 'Digital Prosumer". Journal of Consumer Culture 10 (1): 13-36.

Scholz, Trebor, ed. 2012. Digital Labor: The Internet as Playground and Factory. London: Routledge.

Thrift, Nigel. 2005. Knowing Capitalism. London: Sage.

Toffler, Alvin. 1980. The Third Wave. New York: William Morrow.

Touraine, Alain. 1971. Post-Industrial Society. New York: Random House.

Urry, John. 2002. Global Complexity. Cambridge, UK: Polity Press.

Zukin, Sharon. 2005. Point of Purchase: How Shopping Changed American Culture. London: Routledge. 